\title{
Emission Reduction from Transportation Sector Using Carbon Footprint
}

\author{
Christia Meidiana \\ Regional and Urban Department \\ Brawijaya University \\ Malang, Indonesia \\ c_meideiana@ub.ac.id \\ Deni Agus Setiyono \\ Regional and Urban Department \\ Brawijaya University \\ Malang, Indonesia \\ deni.agus@ub.ac.id
}

\author{
Noufal Riziqi N Rohman \\ Regional and Urban Department \\ Brawijaya University \\ Malang, Indonesia \\ noufalnr@student.ub.ac.id \\ Adina Khusnudzan Hadid \\ Regional and Urban Department \\ Brawijaya University \\ Malang, Indonesia \\ adinahadid@student.ub.ac.id
}

\begin{abstract}
Sidoarjo urban area is an area with different type of activities, such as settlement, trade, services, government, and also public service such as schools and hospitals. Different type of activities generate high levels of transportation activity resulting in high level of $\mathrm{CO}_{2}$ emissions. The purpose of this research is to determine the appropriate solution for $\mathrm{CO}_{2}$ emission reduction from transportation activity. Emission reduction was calculated as a result of different between transportation-borne- $\mathrm{CO}_{2}$ generation and emission absorption. Absorptive capacity analysis was conducted to calculate the current amount of emissions absorbed by plants. Calculation result showed that $\mathrm{CO}_{2}$ emissions at weekday is higher than at weekend which is 3,256.15 tons and 2,962.01 tons respectively, while the absorption ability of plant in current green space is approximately only $3.8 \mathrm{~kg}$ per hour. With this result the solution is needed to reduce $\mathrm{CO}_{2}$ emissions from transportation activity. Referring to the result from the above analysis, two strategies were defined, i.e. adding the area of green space and shifting the fuel consumption from diesel and gasoline to biodiesel and bioethanol respectively. Meanwhile, gas is used to substitute gasoline consumption in public transportation. Required area and type of green spaces was defined and calculated to find out the expected absorption capacity. The amount of emission reduction increased as shifting final energy consumption from transportation sector was applied.
\end{abstract}

Keywords: emission reduction, transportation, bio-capacity

\section{INTRODUCTION}

Air pollution is the main problem in urban areas caused by increasing urbanization rate and loss of open spaces [1]. This condition leads to air quality degradation having adverse effect on health [2]. Three determinants influencing the air quality in urban areas are increasing population, urbanization, and industrialization [3]. Therefore, measures to reduce the greenhouse gas (GHGs) emission are demanding to avoid health problems in urban areas [4]. Measurement can be determined properly if emission is calculated beforehand. Life cycle assessment (LCA) is a method to calculate the emission once goods (product or service) is produced, consumed and disposed [5]. LCA can describe also the effect of the product on environment during their life cycle [6]. Meanwhile, carbon footprint measures the amount of carbon emission generated by an activity direct and indirectly. The activity sources may an individual, group, government, firms, or organization [7]. One of the activities in urban areas contributing emission is transportation. Transportation contributes emission significantly from fossil fuel burning [8]. Transportation sector is mostly needed for mobilization including goods and services [9]. The sources of emission from transportation includes all light and heavy vehicles [10]. One of the reasonable measures for emission reduction from transportation sector can be implemented in developing countries is traffic controlling and urban landscaping. The concept of bio-capacity has been developed to accommodate the demand of carbon absorption [11].

\section{LITERATURE REVIEW}

\section{A. Emission Calculation}

IPCC 2006 Guidelines for National Greenhouse Gas Inventories is used for emission calculation analysis. Certain formula is used based on the $\mathrm{CO}_{2}$ generated form transportation activities and thus is used to calculate the $\mathrm{CO}_{2}$ emission in each grid. Each grid's size is decided with 0.25 $\mathrm{km} \times 0.25 \mathrm{~km}$ size [12]. Therefore, there are 36 grids used to cover the whole area of Sidoarjo City. Furthermore the calculation for number of vehicles within the grid area are measured during the peak hour which consists of 4 different sessions, then the calculation of mileage is done with (1).

$$
S=l \times n
$$

Where:

$S=$ Distance $[\mathrm{km}]$

$l=$ Road length $[\mathrm{km}]$

$n=$ Number of vehicles

The value of mileage (S) is used to calculate the total fuel consumption with (2).

$$
C_{t o t}=S x C_{e}
$$

Where:

$$
\begin{aligned}
& S \quad=\text { Distance }[\mathrm{km}] \\
& \left.C_{t o t}=\text { Total fuel consumption [liter }\right]
\end{aligned}
$$


$\mathrm{C}_{\mathrm{e}}=$ Energy consumption [liter $/ \mathrm{km}$ ]

TABLE I shows the default values for energy consumption for different vehicle types.

TABLE I. VEHICLE ENERGY CONSUMPTION

\begin{tabular}{|l|l|}
\hline \multicolumn{1}{|c|}{ Type of vehicle } & \multicolumn{1}{c|}{ Energy Consumption [liter/km] } \\
\hline $\begin{array}{l}\text { Car/public transportation } \\
\text { (angkot) }\end{array}$ & 0.118 \\
\hline Bus & 0.169 \\
\hline Mini Bus & 0.118 \\
\hline Taxi & 0.109 \\
\hline Truck & 0.158 \\
\hline Pick-up & 0.081 \\
\hline Motorbike & 0.027 \\
\hline
\end{tabular}

The result from calculation of total fuel consumption is further used to determine energy consumption value $(E c)$ with (3). Energy consumption value is the result of conversion from fuel consumption using conversion factor (F) based on the types of fuel is used (gasoline or diesel) as it is explained in TABLE II.

$$
E_{c}=C_{t o t} x F
$$

Where:

$E_{c} \quad$ Energy consumption

$C_{\text {tot }}=$ Total energy consumption [liter]

$F \quad=$ Conversion factor

TABLE II. CONVERSION FACTOR

\begin{tabular}{|l|l|}
\hline \multicolumn{1}{|c|}{ Fuel Type } & \multicolumn{1}{c|}{ Conversion Factor } \\
\hline Gasoline & 0.03466 \\
\hline Diesel & 0.03868 \\
\hline
\end{tabular}

Energy consumption value is further used to calculate the emission by multiplying total energy consumption with emission factor (EF) as it is explained in (4). The EF value is presented in TABLE III.

$$
E_{m}=E_{c} x E F
$$

Where:

$E_{m} \quad=$ Emission

$E_{c} \quad=$ Total energy consumption [liter]

$E F=$ Emission factor

TABLE III. EMISSION FACTOR VALUE

\begin{tabular}{|l|l|}
\hline \multicolumn{1}{|c|}{ Fuel Type } & \multicolumn{1}{c|}{ Emission Factor } \\
\hline Gasoline & 69.3 \\
\hline Diesel & 74.1 \\
\hline
\end{tabular}

\section{B. Biocapacity}

Calculation of residue from emission which is not absorbed by the trees is done by subtracting the emission value $\left(E_{m}\right)$ and absorption rate of trees $(A b s)$ as it explained in formula (5).

$$
\Delta E_{m}=E_{m}-A b s
$$

Where:

$$
\begin{array}{ll}
E_{m} & =\text { Emission }[\mathrm{kg}] \\
\Delta E_{m} & =\text { Residue }[\mathrm{kg}] \\
A b s & =\text { Absorption }[\mathrm{kg} / \text { tree }]
\end{array}
$$

Value of tree absorption rate (Abs) can be categorized based on the types of tree that further is categorized from both local and its scientific name. The value is referring to the previous study from [13] as explained in TABLE IV.

\section{TABLE IV. ABSORPTION OF $\mathrm{CO}_{2}$}

\begin{tabular}{|l|l|l|l|}
\hline No. & Local Name & Scientific Name & $\begin{array}{c}\text { Absorption of CO } \\
\text { (Kg/tree/year) }\end{array}$ \\
\hline 1. & Trembesi & Samanea saman & 28448.39 \\
\hline 2. & Kenanga & $\begin{array}{l}\text { Canangium } \\
\text { odoratum }\end{array}$ & 756.59 \\
\hline 3. & Pingku & $\begin{array}{l}\text { Dysoxylum } \\
\text { excelsum }\end{array}$ & 720.49 \\
\hline 4. & Beringin & Ficus benyamina & 535.90 \\
\hline 5. & Krey Payung & $\begin{array}{l}\text { Fellicium } \\
\text { decipiens }\end{array}$ & 404.83 \\
\hline 6. & Mahoni & $\begin{array}{l}\text { Swettiana } \\
\text { mahagoni }\end{array}$ & 295.73 \\
\hline 7. & Saga & $\begin{array}{l}\text { Adenanthera } \\
\text { pavoiana }\end{array}$ & 221.18 \\
\hline 8. & Johar & Cassia grandis & 116.25 \\
\hline 9. & Puspa & Schima wallichii & 63.31 \\
\hline 10. & $\begin{array}{l}\text { Akasia } \\
\text { auriculifornis) }\end{array}$ & $\begin{array}{l}\text { Acacia } \\
\text { auriculiformis }\end{array}$ & 48.68 \\
\hline 11. & Flamboyan & Delonix regia & 42.20 \\
\hline 12. & Sawo Kecik & Manikara kauki & 36.19 \\
\hline 13. & Tanjung & Mimusops elengi & 34.29 \\
\hline 14. & Bunga Merak & $\begin{array}{l}\text { Caesalpinia } \\
\text { pulcherrima }\end{array}$ & 30.95 \\
\hline 15. & Khaya & Khaya anthotheca & 21.90 \\
\hline 16. & Merbau Pantai & Intsia bijuga & 19.25 \\
\hline 17. & $\begin{array}{l}\text { Akasia } \\
\text { (mangium) }\end{array}$ & $\begin{array}{l}\text { Acacia mangium } \\
\text { Excelsa }\end{array}$ & 15.19 \\
\hline 18. & Angsana & $\begin{array}{l}\text { Pterocarpus } \\
\text { indicus }\end{array}$ & 11.12 \\
\hline 19. & Dadap Merah & $\begin{array}{l}\text { Erythrina } \\
\text { cristagalli }\end{array}$ & 4.55 \\
\hline 20. & Asam & $\begin{array}{l}\text { Tamarindus } \\
\text { indica }\end{array}$ & 1.49 \\
\hline 21. & Kempas & $\begin{array}{l}\text { Coompasia } \\
\text { excen }\end{array}$ \\
\hline
\end{tabular}

\section{Sampling Method}

Scope of field study is determined by the number of grids which refer to the guidelines [12]. The rules to determine the number of grids is determined by the size of the city or region of interest as it explained:

- City or region with area $>100 \mathrm{~km}^{2}$, size of grid is 1 $\mathrm{km} \times 1 \mathrm{~km}$ wide

- City or region with area $<100 \mathrm{~km}^{2}$, size of grid is 0.5 $\mathrm{km} \times 0.5 \mathrm{~km}$ or $0.25 \mathrm{~km} \times 0.25 \mathrm{~km}$ wide

The area of Sidoarjo City is less than $100 \mathrm{~km}^{2}$, therefore the size of grid is $0.25 \mathrm{~km} \mathrm{x} 0.25 \mathrm{~km}$ wide and 36 grids in total. Furthermore, the sampling method consists on 3 different subjects, which consists of transportation, trees and household with each rule are described below. 
- Transportation sampling method is done by calculating every vehicles across within the grids

- Trees sampling method is done by calculating number of tree based on its types as it is explained within TABLE IV, and located within the public area.

- Household energy consumption is done regardless the types or the criteria of the household, all household is considered has same characteristics.

\section{RESUlTS AND DISCUSSION}

\section{A. Green Zone}

Greenspace in Sidoarjo City has the area of $\pm 272 \mathrm{Ha}$ wide which consists of parks, green way, and cemeteries. Green way consists of river borders, railway borders, high voltage air ducts borders, road median, and roundabouts. There are many types of trees that can be planted and further can be used as greenspace with different purposes. The number of trees within the field of study area is explained within TABLE V.

TABle V. Number of Trees IN the AREA of Study

\begin{tabular}{|l|l|l|l|}
\hline No. & Local Name & \multicolumn{1}{|c|}{ Scientific Name } & Number of Trees \\
\hline 1. & Johar & Cassia grandis & 30 \\
\hline 2. & Kirei Payung & Fellicium decipiens & 65 \\
\hline 3. & Angsana & Pterocarpus indicus & 284 \\
\hline
\end{tabular}

\section{B. Greenhouse Gas Emission from Transportation}

\section{1) Weekday}

Emission of $\mathrm{CO}_{2}$ was calculated from every grid used in this research with the total number of 36 grids. The number of vehicles, types of fuel, road length of every grid, and emission factor value are considered within the calculation of emission. The result shows that motorbike produced the highest emission, while the lowest emission is produced by taxi. Even though larger vehicles such as truck and bus has higher fuel consumption, but their number are too low compared to motorbike, car and taxi. Thus they produce less emission.

Car and motorbike are the main contributor to $\mathrm{CO}_{2}$ emission in every grids. It indicates that private vehicles is the most favorable transportation mode for people to commute. Mini bus or bus as a mode of public transportation produces few or even no $\mathrm{CO}_{2}$ emission. The emission is emitted mainly in the morning and the evening because it is the time when people commute at most to start their daily activities or commute back to their home. The distribution of emission during the weekdays is showed in Fig. 1. The calculation comes to the result that total emission during the weekdays is 3256.15 tons/hour.

\section{2) Weekend}

Calculation of $\mathrm{CO}_{2}$ emission during weekends was applied to confirm the difference of $\mathrm{CO}_{2}$ emitted from vehicles due to the difference in number of vehicles during weekday and weekend. Motorbike still emits the highest $\mathrm{CO}_{2}$, but the amount is less compared to the emission in weekdays. On the contrary, car produces higher emission in weekends compared to weekday. This result relates with the fact that most people have different destination of commuting during weekday which is mainly related for working or school activities, and weekend which mainly relates with recreation purpose. In weekends, the emission is the highest during afternoon and evening, which is different compared to that of in weekdays. Fig. 2 presents the distribution of emission during the weekends and the total emission is 2962.01 tons/hour.

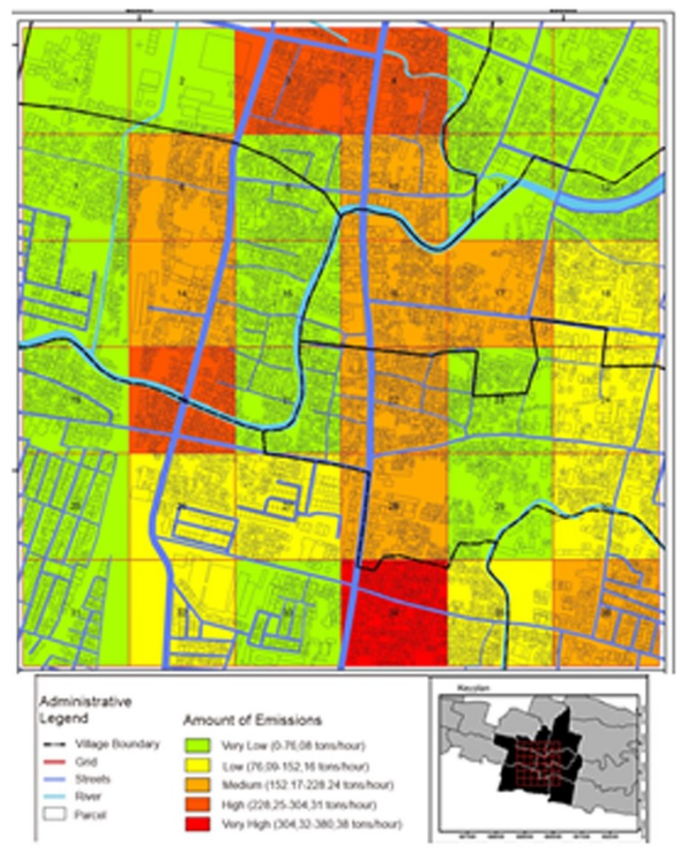

Fig. 1. Emission Distribution on Weekdays.

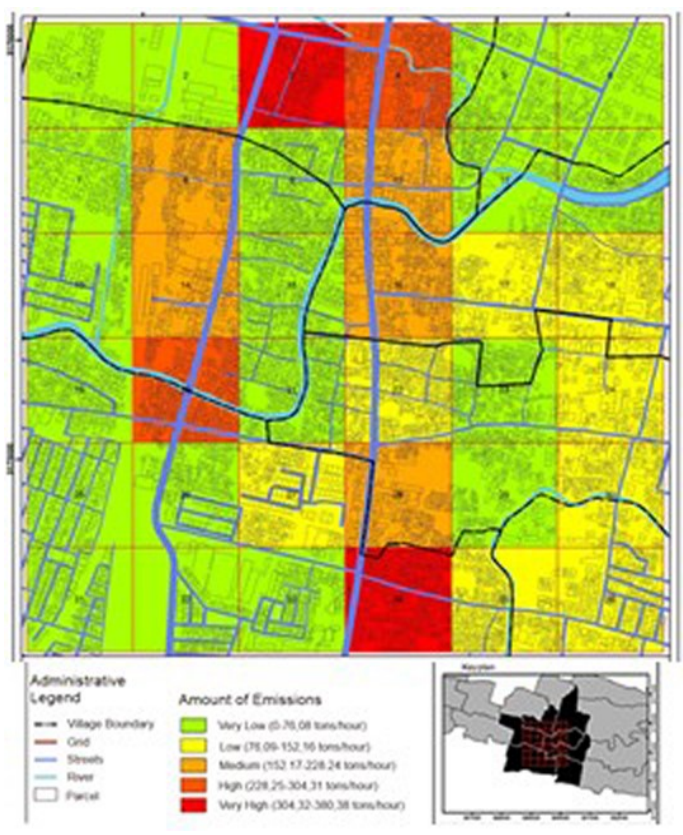

Fig. 2. Distribution of Emission on Weekends. 


\section{Emission Reduction Calculation Through Absorption}

Referring to (5), total absorption of emission was calculated according to the bio-capacity of each tree type showed in TABLE V. Three kinds of tree were used in the calculation, i.e. Angsana tree, Johar tree and Kirey payung tree because these trees are appropriate to be planted in area of study in comply with local regulation.

TABLE VI. CURRENT BIocAPACITY IN AREA OF STUdY

\begin{tabular}{|c|c|c|c|c|}
\hline Cell & $\begin{array}{c}\text { Angsana } \\
{[0.0012} \\
\mathrm{Kg}] \\
\end{array}$ & $\begin{array}{c}\text { Johar } \\
{[0.0132 \mathrm{Kg}]}\end{array}$ & $\begin{array}{c}\text { Kirei } \\
\text { Payung } \\
{[0.046 \mathrm{Kg}]}\end{array}$ & $\begin{array}{c}\text { Total } \\
\text { Bio-capacity } \\
{[\mathrm{kg} / \mathrm{hour}]}\end{array}$ \\
\hline 1 & - & - & - & \\
\hline 2 & 2 & - & - & 0.00254 \\
\hline 3 & 2 & - & - & 0.00254 \\
\hline 4 & - & - & - & - \\
\hline 5 & 40 & - & - & 0.05078 \\
\hline 6 & 30 & 6 & 4 & 0.30256 \\
\hline 7 & - & - & - & - \\
\hline 8 & 6 & - & - & 0.00762 \\
\hline 9 & - & - & - & - \\
\hline 10 & - & - & 6 & 0.27728 \\
\hline 11 & 20 & - & 18 & 0.85723 \\
\hline 12 & 6 & 2 & - & 0.03416 \\
\hline 13 & - & - & - & - \\
\hline 14 & 4 & - & - & 0.00508 \\
\hline 15 & - & - & - & - \\
\hline 16 & - & - & - & - \\
\hline 17 & 20 & 4 & 4 & 0.26332 \\
\hline 18 & 18 & 2 & 2 & 0.14182 \\
\hline 19 & - & - & - & - \\
\hline 20 & 6 & - & 2 & 0.10004 \\
\hline 21 & - & 2 & - & 0.02654 \\
\hline 22 & - & - & - & - \\
\hline 23 & 6 & - & 4 & 0.19247 \\
\hline 24 & 24 & 2 & 6 & 0.33429 \\
\hline 25 & 2 & - & - & 0.00254 \\
\hline 26 & 28 & - & - & 0.03554 \\
\hline 27 & - & 2 & 2 & 0.11897 \\
\hline 28 & 14 & - & - & 0.01777 \\
\hline 29 & - & - & - & - \\
\hline 30 & 10 & 4 & 6 & 0.34306 \\
\hline 31 & - & - & - & - \\
\hline 32 & 20 & - & - & 0.02539 \\
\hline 33 & 6 & 2 & 4 & 0.21901 \\
\hline 34 & 6 & 2 & - & 0.03416 \\
\hline 35 & - & 2 & 6 & 0.30382 \\
\hline 36 & 10 & - & 2 & 0.10512 \\
\hline Total & 280 & 30 & 66 & 3.80000 \\
\hline
\end{tabular}

TABLE VI shows that current bio-capacity is too low to absorbs the emission both in weekdays and weekends. It can reduce emission only about $0.1 \%$. Therefore, two measurements are proposed to increase the emission reduction i.e. increasing the bio-capacity by planting more trees and shifting the fuel from fossil to renewable energy.

TABLE VII presents the first measurement and the result shows that it can reduce the emission up to $0.6 \%$.
TABLE VII. BIOCAPACITY AFTER MEASUREMENT

\begin{tabular}{|c|c|c|c|c|}
\hline Cell & Trees & Number & $\begin{array}{c}\text { Biocapacity } \\
\text { (ton/hour) }\end{array}$ & $\begin{array}{c}\text { Total } \\
\text { (ton/hour) }\end{array}$ \\
\hline \multirow{3}{*}{1} & Kenanga & 38 & 0.0032820 & \multirow{3}{*}{0.0033502} \\
\hline & Tanjung & 10 & 0.0000391 & \\
\hline & Dadap & 56 & 0.0000291 & \\
\hline \multirow{4}{*}{2} & Dadap & 48 & 0.0000249 & \multirow{4}{*}{0.0257898} \\
\hline & Kenanga & 22 & 0.0019001 & \\
\hline & Kenanga & 180 & 0.0155464 & \\
\hline & $\begin{array}{l}\text { krey } \\
\text { paying }\end{array}$ & 180 & 0.0083184 & \\
\hline 3 & Kenanga & 34 & 0.0029365 & 0.0029365 \\
\hline \multirow{2}{*}{4} & kenanga & 10 & 0.0008637 & \\
\hline & kenanga & 14 & 0.0012092 & \\
\hline 5 & - & - & - & 0 \\
\hline 6 & kenanga & 24 & 0.0020728 & 0.0020728 \\
\hline \multirow{2}{*}{7} & kenanga & 6 & 0.0005182 & \multirow{2}{*}{0.0042321} \\
\hline & kenanga & 43 & 0.0037139 & \\
\hline \multirow{3}{*}{8} & kenanga & 59 & 0.0050958 & \multirow{3}{*}{0.0105861} \\
\hline & $\begin{array}{l}\text { krey } \\
\text { payung }\end{array}$ & 59 & 0.0027266 & \\
\hline & kenanga & 32 & 0.0027638 & \\
\hline 9 & - & - & - & 0 \\
\hline 10 & - & - & - & 0 \\
\hline 11 & kenanga & 50 & 0.0043184 & 0.0043184 \\
\hline \multirow{2}{*}{12} & kenanga & 21 & 0.0018137 & \multirow{2}{*}{0.0101051} \\
\hline & kenanga & 96 & 0.0082914 & \\
\hline \multirow{4}{*}{13} & kenanga & 45 & 0.0038866 & \multirow{4}{*}{0.0125901} \\
\hline & kenanga & 82 & 0.0070822 & \\
\hline & $\begin{array}{l}\text { krey } \\
\text { payung }\end{array}$ & 22 & 0.0010167 & \\
\hline & kenanga & 7 & 0.0006046 & \\
\hline \multirow{4}{*}{14} & $\begin{array}{l}\text { krey } \\
\text { payung }\end{array}$ & 21 & 0.0009705 & \multirow{4}{*}{0.0068117} \\
\hline & $\begin{array}{l}\text { krey } \\
\text { payung }\end{array}$ & 18 & 0.0008318 & \\
\hline & kenanga & 18 & 0.0015546 & \\
\hline & kenanga & 40 & 0.0034547 & \\
\hline 15 & - & - & - & 0 \\
\hline 16 & kenanga & 12 & 0.0010364 & 0.0010364 \\
\hline \multirow{4}{*}{17} & kenanga & 30 & 0.0025911 & \multirow{4}{*}{0.0115734} \\
\hline & kenanga & 30 & 0.0025911 & \\
\hline & kenanga & 59 & 0.0050958 & \\
\hline & kenanga & 15 & 0.0012955 & \\
\hline 18 & - & - & - & 0 \\
\hline \multirow{5}{*}{19} & kenanga & 7 & 0.0006046 & \multirow{5}{*}{0.0101983} \\
\hline & kenanga & 13 & 0.0011228 & \\
\hline & kenanga & 29 & 0.0025047 & \\
\hline & kenanga & 45 & 0.0038866 & \\
\hline & $\begin{array}{l}\text { krey } \\
\text { payung }\end{array}$ & 45 & 0.0020796 & \\
\hline \multirow{3}{*}{20} & kenanga & 24 & 0.0020728 & \\
\hline & kenanga & 44 & 0.0038002 & 0.0079065 \\
\hline & $\begin{array}{l}\text { krey } \\
\text { payung }\end{array}$ & 44 & 0.0020334 & \\
\hline 21 & kenanga & 26 & 0.0022456 & 0.0022456 \\
\hline 22 & - & - & - & 0 \\
\hline 23 & Kenanga & 14 & 0.0012092 & 00034547 \\
\hline & Kenanga & 26 & 0.0022456 & \\
\hline 24 & - & - & - & 0 \\
\hline 25 & Kenanga & 5 & 0.0004318 & $0=501560$ \\
\hline 25 & Kenanga & 152 & 0.0065640 & 0.5401553 \\
\hline
\end{tabular}




\begin{tabular}{|c|c|c|c|c|}
\hline Cell & Trees & Number & $\begin{array}{c}\text { Biocapacity } \\
\text { (ton/hour) }\end{array}$ & $\begin{array}{c}\text { Total } \\
\text { (ton/hour) }\end{array}$ \\
\hline & & & 0.0065640 & \\
\hline & trembesi & 164 & 0.5325954 & \\
\hline \multirow{7}{*}{26} & Kenanga & 22 & 0.0019001 & \multirow{7}{*}{4.9683775} \\
\hline & Kenanga & 16 & 0.0013819 & \\
\hline & Kenanga & 26 & 0.0022456 & \\
\hline & Kenanga & 11 & 0.0009501 & \\
\hline & Kenanga & 22 & 0.0019001 & \\
\hline & $\begin{array}{l}\text { krey } \\
\text { payung }\end{array}$ & 22 & 0.0010167 & \\
\hline & trembesi & 1527 & 4.9589831 & \\
\hline \multirow{3}{*}{27} & Kenanga & 6 & 0.0005182 & \multirow{3}{*}{0.0049230} \\
\hline & Kenanga & 40 & 0.0034547 & \\
\hline & Kenanga & 11 & 0.0009501 & \\
\hline \multirow{2}{*}{28} & Kenanga & 36 & 0.0031093 & \multirow{2}{*}{0.0043184} \\
\hline & Kenanga & 14 & 0.0012092 & \\
\hline \multirow{4}{*}{29} & Kenanga & 31 & 0.0026774 & \multirow{4}{*}{0.0154600} \\
\hline & Kenanga & 6 & 0.0005182 & \\
\hline & Kenanga & 68 & 0.0058731 & \\
\hline & Kenanga & 74 & 0.0063913 & \\
\hline \multirow{3}{*}{30} & kenanga & 34 & 0.0029365 & \multirow{3}{*}{0.0185693} \\
\hline & Kenanga & 90 & 0.0077732 & \\
\hline & Kenanga & 91 & 0.0078596 & \\
\hline \multirow{5}{*}{31} & Kenanga & 50 & 0.0043184 & \multirow{5}{*}{3.9142084} \\
\hline & $\begin{array}{l}\text { krey } \\
\text { paying }\end{array}$ & 50 & 0.0023107 & \\
\hline & Kenanga & 55 & 0.0047503 & \\
\hline & $\begin{array}{l}\text { krey } \\
\text { paying }\end{array}$ & 55 & 0.0025417 & \\
\hline & Trembesi & 1201 & 3.9002873 & \\
\hline \multirow{2}{*}{32} & Kenanga & 35 & 0.0030229 & \multirow{2}{*}{13.8277713} \\
\hline & Trembesi & 4257 & 13.8247484 & \\
\hline \multirow{2}{*}{33} & Kenanga & 12 & 0.0010364 & \multirow{2}{*}{0.0025911} \\
\hline & Kenanga & 18 & 0.0015546 & \\
\hline 34 & Kenanga & 18 & 0.0015546 & 0.0015546 \\
\hline \multirow{5}{*}{35} & Dadap & 9 & 0.0000047 & \multirow{5}{*}{0.0168544} \\
\hline & Dadap & 15 & 0.0000078 & \\
\hline & Kenanga & 85 & 0.0073413 & \\
\hline & Kenanga & 86 & 0.0074277 & \\
\hline & Kenanga & 24 & 0.0020728 & \\
\hline \multirow[t]{2}{*}{36} & Dadap & 12 & 0.0000062 & 0.0000062 \\
\hline & & & $\begin{array}{l}\text { Total bio- } \\
\text { capacity }\end{array}$ & 23.4420704 \\
\hline
\end{tabular}

The second measurement can be applied using the following assumption:

1. Gasoline can be substituted with Bioethanol which can reduce the emission up to $48 \%$.

2. Solar can be substituted with Biodiesel which can reduce the emission up to $74 \%$.

3. Public transportation (angkot) can shift the fuel from gasoline to gas generating $30 \%$ less emission and gas is cheaper than gasoline.

Calculation using above assumptions comes to the result of the following emission reduction (TABLE VIII and TABLE IX).
TABLE VIII. EMISSION REDUCTION ON WEEKDAYS

\begin{tabular}{|l|l|l|l|l|}
\hline \multicolumn{1}{|c|}{ Type } & Emission & $\begin{array}{c}\text { Absorption } \\
(\mathbf{A b s})\end{array}$ & $\begin{array}{c}\text { Reduction } \\
{[\% \mathbf{\%}\}}\end{array}$ & $\begin{array}{c}\text { Residue } \\
(\mathbf{\Delta E m})\end{array}$ \\
\hline Motorbike & $1,749.69$ & 839.85 & $48 \%$ & 909.84 \\
\hline Car & $1,247.69$ & 598.89 & $48 \%$ & 648.8 \\
\hline Angkot & 135.49 & 132.53 & $30 \%$ & 94.74 \\
\hline Taxi & 13.57 & 6.51 & $48 \%$ & 7.06 \\
\hline Pick Up & 54.28 & 52.52 & $74 \%$ & 14.11 \\
\hline Mini Bus & 56.58 & 55.11 & $74 \%$ & 14.71 \\
\hline Bus & 15.26 & 14.95 & $74 \%$ & 3.97 \\
\hline Truck & 52.74 & 51.77 & $74 \%$ & 13.71 \\
\hline
\end{tabular}

TABLE IX. EMISSION REDUCTION ON WEEKENDS

\begin{tabular}{|l|l|l|l|l|}
\hline \multicolumn{1}{|c|}{ Type } & Emission & $\begin{array}{c}\text { Absorption } \\
(\mathbf{A b s})\end{array}$ & $\begin{array}{c}\text { Reduction } \\
{[\% \boldsymbol{\%}}\end{array}$ & $\begin{array}{c}\text { Residue } \\
(\mathbf{\Delta E m})\end{array}$ \\
\hline Motorbike & $1,423.24$ & 683.16 & $48 \%$ & 740.09 \\
\hline Car & $1,261.37$ & 605.46 & $48 \%$ & 655.91 \\
\hline Angkot & 128.6 & 38.6 & $30 \%$ & 90.07 \\
\hline Taxi & 15.26 & 7.32 & $48 \%$ & 7.93 \\
\hline Pick Up & 42.75 & 31.56 & $74 \%$ & 11.11 \\
\hline Mini Bus & 49.01 & 34.91 & $74 \%$ & 12.74 \\
\hline Bus & 9.44 & 6.99 & $74 \%$ & 2.46 \\
\hline Truck & 32.27 & 23.28 & $74 \%$ & 8.39 \\
\hline
\end{tabular}

Shifting the fossil fuel to biofuel and gas can reduce the emission of $49 \%$ and $48 \%$ on weekday and weekend respectively.

\section{CONCLUSIONS}

The highest emission rate is in cell 34 on weekdays which is 380.38 ton/hour and cell 34 on weekends which is 336.36 ton/hour because there is higher transportation volume caused by the more activities during those times. Totally, the emission rate is approximately 3256.15 ton/hour and 2962.01 ton/hour on weekdays and weekends respectively. Motorbike generates the highest emission both during the weekdays and weekends, while bus emits the least emission at the same period.

The current number of trees in the area of study reduce the emission from transportation insignificantly which is only about $0.01 \%$. By adding the area of the green space and the number of the trees, the emission reduction increases although still low amounting to around $0.6 \%$.

Shifting the fuel from fossil to other alternative fuels, such as bioethanol, biodiesel and gas can reduce more emission up to $49 \%$ on weekdays (1840.91 ton/hour) and weekends (1587.49 ton/hour).

\section{REFERENCES}

[1] Pandey, A.K., Air Pollution Tolerance Index and Anticipated Performance Index of Some Plant Species for Development of Urban Forest, Urban Forestry and Urban Greening. http://dx.doi.org/10.1016/j.ufug.2015.08.001. 2015.

[2] Kanakidou M et al., Megacities as hot spots of air pollution in the East Mediterranean Atmospheric Environment 45:1223-1235. 2011.

[3] Cavanagh J-AE, Zawar-Reza P,Wilson JG. Spatial Attenuation of Ambient Particulate Matter Air Pollution Within an Urbanised Native Forest Patch, Urban Forestry \& Urban Greening. 8:21-30 doi:http://dx.doi.org/10.1016/j.ufug.2008.10.002. 2009.

[4] Metz, B., Davidson, O., Bosch, P. \& Dave, R., Contribution of working group III to the fourth assessment report of the 
intergovernmental panel on climate change, 2007. Cambridge/New York: Cambridge University Press. 2007.

[5] Pauleit, S. \& Duhme, F., Assessing the environmental performance of land cover types for urban planning. Landscape and Urban Planning, 52(1), 1-20. 2000.

[6] Tukker, A., Life Cycle Assessment as a Tool in Environmental Impact Assessment. Environmental Impact Assessment Review, 20, 435-456.http://dx.doi.org/10.1016/S0195-9255(99)00045-1. 2000.

[7] Wiedmann, T. and Minx, J., A Definition of 'Carbon Footprint'. In: C. C. Pertsova, Ecological Economics Research Trends: Chapter 1, pp. 1-11, Nova Science Publishers, Hauppauge NY, USA. https://www.novapublishers.com/catalog/product_info.php?products id $=5999.2008$.

[8] Indonesian Ministry of National Development Planning. Indonesia Climate Change Sectoral Roadmap (ICCSR). National Development Planning Agency. Jakarta. 2009 (in IndonesiaN).

[9] Miro, F. Transportation Planning for Students, Planners and Practitioners (In Indonesian). Erlangga. Jakarta. 2005.

[10] IPCC 2006, 2006 IPCC Guidelines for National Greenhouse Gas Inventories, Prepared by the National Greenhouse Gas Inventories Programme, Eggleston H.S., Buendia L., Miwa K., Ngara T., and Tanabe K. (eds). Published: IGES, Japan.

[11] Nowak, D. J. \& Crane, D. E. Carbon storage and sequestration by urban trees in the USA. Environmental Pollution, 116(3), 381-389. 2002.

[12] Ministry of Environment. Technical Guidelines for Preparing an Inventory of Air Pollutant Emissions in Urban Areas (In Indonesian). Jakarta. 2013.

[13] Dahlan, E. N., Analysis of the Needs of the Area of Urban Forests as Anthropogenic $\mathrm{CO} 2$ Gas Sinks and Oil and Gas Fuels in the Bogor City with a Dynamic System Approach (in Indonesian). Disertation. Bogor: Faculty of Forestry, Bogor Agricultural University. 2007. 